\title{
Zmiany znaczeniowe wybranych czasowników mówienia zanikających w dobie nowopolskiej
}

\section{Semantic changes of selected verbs of speech disappearing in the new Polish period}

\author{
Ewelina Kwapień \\ Wydział Polonistyki, Uniwersytet Warszawski, \\ ul. Krakowskie Przedmieście 26/28, 00-927 Warszawa, Polska \\ e-mail: e.m.kwapien@uw.edu.pl
}

\begin{abstract}
Abstrakt
Artykuł dotyczy zmian znaczeniowych wybranych czasowników mówienia, określonych w źródłach leksykograficznych jako nacechowane chronologicznie dawnością. Podstawę badawczą stanowią wyekscerpowane na podstawie Stownika języka polskiego, red. W. Doroszewski, t. 1-11, PAN, Warszawa 1958-1969 (reprint) czasowniki z kwalifikatorami dawne, przestarzałe, wychodzace $z$ użycia. Analizie leksykograficznej zostało poddanych 25 jednostek leksykalnych uznanych za czasowniki mówienia, które oprócz kwalifikatorów chronologicznych miały także inne kwalifikatory wskazujące na jakieś ograniczenia związane z ich użyciem (np. gwarowe, potoczne, żartobliwe itp.). Informacje leksykograficzne potwierdzają istnienie różnorodnych procesów związanych z kształtowaniem się nowych i zanikaniem już niepotrzebnych znaczeń.
\end{abstract}

Słowa kluczowe: czasowniki mówienia; zmiany znaczeniowe; doba nowopolska.

\begin{abstract}
The paper presents semantic changes to verbs of speech. These verbs are identified as obsolete in the lexicographical sources. The material was collected from Słownik języka polskiego, ed. W. Doroszewski, vol. 1-11, PAN, Warszawa 1958-1969 (reprint) and contains verbs qualified as: archaic, obsolete and getting out of use. 25 lexical units considered verbs of speech were analysed. These units have chronological and other qualifiers (e.g. dialectal, colloquial, humorous). Lexicographic data confirms the presence of various processes associated with the emergence of new and disappearance of unwanted meanings.
\end{abstract}

Keywords: verbs of speech; semantic changes; the new Polish period.

Celem artykułu jest przyjrzenie się zmianom znaczeniowym wybranych czasowników mówienia zanikających w dobie nowopolskiej. Podstawę badawczą artykułu stanowią czasowniki wybrane z SJPD, oznaczone kwalifikatorami dawne, przestarzałe, wychodzace z użycia; sygnalizującymi, że są to jednostki leksykalne ${ }^{1}$ wychodzące

${ }^{1}$ Przez jednostkę leksykalną rozumiem każdą jednostkę samodzielną semantycznie, czyli w tym wypadku każde ze znaczeń danego czasownika. 
z użycia w dobie nowopolskiej. Na tym etapie pracy dokonano ekscerpcji z tomów obejmujących litery A-N, uzyskując 1595 jednostek leksykalnych. Spośród nich przedmiotem artykułu stały się czasowniki mówienia.

Wszystkich czasowników mówienia, opatrzonych kwalifikatorami chronologicznymi wskazującymi na regres, w obrębie czasownikowych jednostek leksykalnych od A do N jest 234. Przedmiotem artykułu stało się 25 jednostek, opatrzonych dodatkowymi kwalifikatorami (rzad., przen., przen. rzad., pot., żart., dziś żart., książk., dziś książk., dziś podn. a. żart., gw., dziś gw., reg., dziś reg., reg. wsch.). Pozwala to przyjrzeć się uważniej zmianom znaczeniowym, które ich dotyczyły w dobie nowopolskiej. Analiza leksykograficzna odwołuje się tylko do źródeł obejmujących słownictwo doby nowopolskiej. Jako reprezentatywne wybrane zostały następujące źródła: SL, SWil, SW, SJPD oraz - aby uzyskać szerszą perspektywę - USJP.

Wśród czasowników wychodzących z użycia w dobie nowopolskiej zauważyć można jednostki leksykalne odnoszące się do wszelkich sfer rzeczywistości. Verba dicendi wydają się jednym z najbardziej interesujących, choć jednocześnie skomplikowanych, podzbiorów wyodrębniających się w materiale.

Czasowniki z tej grupy skupiały wielokrotnie zainteresowanie badaczy i to w bardzo różnorodnych ujęciach zarówno w odniesieniu do dawnej (np. Kleszczowa 1989, Kierkowicz 2011), jak i do współczesnej polszczyzny (np. Kozarzewska 1990, Chojak 2006, Stępień 2009). Czasowniki z doby nowopolskiej nie zostały jednak w ten sposób opracowane, w szczególności zaś czasowniki w tym okresie zanikające. Częściowo (jedynie w niewielkim zakresie) są one obecne w opracowaniu Krystyny Kleszczowej (1989), ponieważ uwzględniła ona również materiał z SWil oraz SW.

Kryteria doboru materiału leksykalnego zostały przyjęte za opracowaniem Krystyny Kleszczowej (1989: 19), jednak mimo wyraźnie wytyczonej ścieżki, podjęcie decyzji o włączeniu jednostki leksykalnej do grupy czasowników mówienia nie zawsze było łatwe, przede wszystkim ze względu na fakt, że niekiedy definicje słownikowe nie były jednoznaczne, ale także ze względu na czasami zbyt ubogą ilustrację tekstową analizowanych jednostek w słowniku SJPD. Oczywiście można byłoby prowadzić dalsze poszukiwania źródłowe w tej kwestii, wydaje się jednak, że byłyby one niewspółmierne do efektów, w każdym bowiem wypadku znalazłyby się jednostki w jakiś sposób wątpliwe i znajdujące się na pograniczu. Dzieje się tak między innymi dlatego, że „Czasownik uzyskuje zdolność opisywania mówienia dopiero wtedy, kiedy wejdzie w odpowiedni układ semantyczno-składniowy” (Kleszczowa 1989: 19). Krystyna Kleszczowa stwierdza, że „o uznaniu zdania za opisujące werbalną komunikację decyduje przede wszystkim forma i semantyczna jakość argumentów, a nie sam czasownik. Nawet tradycyjnie uznawane za verba dicendi czasowniki, osadzone w innym schemacie składniowym, tracą zdolność referowania aktu mowy" (Kleszczowa 1989: 19).

Wątpliwości klasyfikacyjne dotyczą dwojakich sytuacji: po pierwsze - gdy typowe czasowniki mówienia w użytym kontekście przestają się odnosić do czyn- 
ności mówienia, po drugie - gdy czasowniki o prymarnych znaczeniach niezwiązanych z mówieniem, w określonym kontekście odnoszą się do aktu komunikacji; w niektórych sytuacjach możliwe jest bowiem oddziaływanie za pomocą komunikatów werbalnych lub za pomocą innych form komunikacji: np. mimiką, gestem. Np. znaczenie czasownika dekurażować zostało sformułowane jako 'odbierać komuś odwagę, energię; zniechęcać, zrażać kogoś'. Ten cel można osiągnąć zarówno poprzez komunikaty mówione, jak i poprzez inne działania, np. zachowanie się w określonej sytuacji, machnięcie ręką, skrzywienie się.

Podczas analizy słownictwa zgromadzonego w źródłach leksykograficznych, istotna jest kwestia kwalifikatorów, odnoszących się bądź do całych artykułów hasłowych, bądź też do pojedynczych tylko znaczeń danego czasownika. W wypadku analizowanego słownictwa kwalifikatory wskazują z jednej strony stopień jego archaiczności, z drugiej zaś informują o zakresie użycia poszczególnych jednostek leksykalnych. Gdyby odnotowano jedynie kwalifikator chronologiczny, należałoby sądzić (oczywiście z zastrzeżeniami co do rozstrzygnięć słownikowych), że mamy do czynienia ze słownictwem ogólnym - standardowym. Zastosowanie dodatkowych kwalifikatorów informuje o tym, że zasięg używanych jednostek leksykalnych był w przeszłości, lub jest obecnie, w jakiś sposób ograniczony. Pod tym kątem została uporządkowana omawiana leksyka. W tabeli 1 . przedstawiono jednostki leksykalne określone w SJPD jako dawne, przy których nie znalazły się żadne dodatkowe kwalifikatory. Oznacza to, że w odczuciu redaktorów słownika w połowie XX wieku owo słownictwo uznane zostało za najbardziej archaiczne w polszczyźnie i jednocześnie o zasięgu ogólnym. Spośród wszystkich czasowników dawnych lub wychodzących z użycia, wyekscerpowanych z tomów na litery A-N to 122 jednostki leksykalne.

Tabela 1. Verba dicendi określone w SJPD jako dawne

\begin{tabular}{|r|l|l|}
\hline Lp. & \multicolumn{1}{|c|}{ Forma hasłowa } & \multicolumn{1}{c|}{ Znaczenie } \\
\hline 1. & adresować się $\mathbf{1}$ & 'zwracać się, udawać się do kogo' \\
\hline 2. & adresować się $\mathbf{2}$ & 'zalecać się' \\
\hline 3. & afektować & $\begin{array}{l}\text { 'wypowiadać się, zachowywać się w sposób przesadny, nienaturalny; } \\
\text { przesadzać, udawać' }\end{array}$ \\
\hline 4. & afrontować & 'czynić komuś afront, uchybiać, znieważać' \\
\hline 5. & aklamować & 'witać okrzykiem; uznawać, powoływać' \\
\hline 6. & angażować & 'angażować do tańca, zamawiać taniec, zapraszać do tańca' \\
\hline 7. & apostrofować & $\begin{array}{l}\text { 'zwracać się do kogoś z wezwaniem; zagadywać kogoś z naciskiem, } \\
\text { z odcieniem nagany' }\end{array}$ \\
\hline 8. & aranżować & 'przewodzić, wodzić rej' \\
\hline 9. & atentować się & $\begin{array}{l}\text { 'składać uszanowanie, okazywać szacunek, starać się o czyjeś względu, } \\
\text { nadskakiwać' }\end{array}$ \\
\hline
\end{tabular}




\begin{tabular}{|c|c|c|}
\hline Lp. & Forma hasłowa & Znaczenie \\
\hline 10. & awanturzyć się & $\begin{array}{l}\text { p. awanturować się 'wszczynać kłótnie, szukać przygód, zaczepek, brać } \\
\text { udział w ryzykownych przedsięwzięciach; pędzić życie awanturnicze, } \\
\text { niespokojne, hulaszcze' }\end{array}$ \\
\hline 11. & badać się & 'wypytywać, dowiadywać się dochodzić, radzić się' \\
\hline 12. & balakać & 'mówić od rzeczy, pleść, bajać' \\
\hline 13. & bałamucić & 'mówić od rzeczy, paplać; wikłać, gmatwać, plątać, wichrzyć' \\
\hline 14. & bałuchać & 'krzyczeć, hałasować' \\
\hline 15. & bałwochwalić & 'uwielbiać, czcić jak bożka' \\
\hline 16. & bastować & 'w grze w karty: mówić basta, pasować' \\
\hline 17. & bęknąć & $\begin{array}{l}\text { p. bąknąć, bąkać w zn. 1: ‘mówić coś niewyraźnie, niezrozumiale, } \\
\text { cicho; mówić coś zdawkowego, mało znaczącego; nieudolnie czytać na } \\
\text { głos, mamrotać'; w zn. } 2 \text { : 'napomykać o czymś w mowie, wspominać; } \\
\text { mówić o czymś nieoficjalnie, po kątach’ }\end{array}$ \\
\hline 18. & blekotać 1 & 'mówić gniewnie, łajać kogoś; fukać, gderać, wymyślać' \\
\hline 19. & blekotać 2 & 'mówić byle co, bez zastanowienia; pleść, paplać' \\
\hline 20. & bramować & 'obmawiać, szkalować' \\
\hline 21. & burować & 'dawać komuś burę, łajać kogoś, burczeć na kogoś' \\
\hline 22. & buzować II & 'łajać kogoś, gromić' \\
\hline 23. & chelstać się & 'robić szum, szmer, zgiełk; szumieć, szemrać, hałasować' \\
\hline 24. & choleryzować & 'gniewać się, złościć się, wymyślać komuś' \\
\hline 25. & ciapać & 'tylko ndk, mówić niewyraźnie, bąkać' \\
\hline 26. & czwanić się & $\begin{array}{l}\text { 'przedstawiać samego siebie w przesadnie korzystnym świetle; chełpić } \\
\text { się, pysznić się, popisywać się' }\end{array}$ \\
\hline 27. & dąć & 'stawać się zarozumiały, pysznić się, zadzierać nosa' \\
\hline 28. & dedukować & 'wyprowadzać, wywodzić' \\
\hline 29. & deferować & 'przedstawiać, proponować; naznaczać coś' \\
\hline 30. & demonstrować & 'wykazywać, dowodzić, uzasadniać' \\
\hline 31. & deprekować & 'przepraszać w obecności świadków' \\
\hline 32. & despektować & 'czynić komuś despekt; ubliżać, uchybiać' \\
\hline 33. & dokazać & 'dowieść, przekonać, udowodnić, wykazać' \\
\hline 34. & $\begin{array}{l}\text { dokładać się } \\
\text { - dołożyć się }\end{array}$ & 'radzić się kogoś, zasięgać czyjegoś zdania' \\
\hline 35. & dopierać II 3 & 'nalegać' \\
\hline 36. & dopomagać się & 'domagać się, upominać się' \\
\hline 37. & dowcipować & p. dowcipkować 'mówić dowcipy, żartować' \\
\hline 38. & dowieść 1 & 'świadczyć na kogoś, oskarżyć kogoś' \\
\hline 39. & dowołać & 'dokończyć wołać, przywołać kogoś jeszcze' \\
\hline 40. & dwoić się 2 & 'różnić się, nie zgadzać się’ \\
\hline
\end{tabular}




\begin{tabular}{|c|c|c|}
\hline Lp. & Forma hasłowa & Znaczenie \\
\hline 41. & dyskursować & 'prowadzić dyskurs, dyskutować, rozprawiać' \\
\hline 42. & dysputować się & 'rozprawiać, spierać się' \\
\hline 43. & dziać 2 & 'z celownikiem: dawać komuś nazwę, imię; nazywać kogoś' \\
\hline 44. & ekskuzować & 'tłumaczyć, wybaczać komuś coś, uniewinniać' \\
\hline 45. & ewangelizować & $\begin{array}{l}\text { 'opowiadać ewangelię, nauczać ewangelii, szerzyć naukę Jezusa } \\
\text { Chrystusa' }\end{array}$ \\
\hline 46. & faktorować & 'wstawiać się, przemawiać za kimś' \\
\hline 47. & felicytować & 'składać życzenia; winszować, gratulować' \\
\hline 48. & fulminować & $\begin{array}{l}\text { 'okazywać niezadowolenie, wyrzekać, oburzać się na kogoś lub coś; } \\
\text { rzucać gromy, gromić' }\end{array}$ \\
\hline 49. & futrować II & 'besztać kogoś, łajać, wymyślać komuś' \\
\hline 50. & gabnąć 2 & 'zaczepić, napastować, oskarżyć' \\
\hline 51. & gaworzyć & 'gadać ni to ni owo; pleść, paplać' \\
\hline 52. & gdyrać & $\begin{array}{l}\text { p. gderać: pot. 'strofować kogoś w sposób dokuczliwy, bez istotnej } \\
\text { potrzeby, z zamiłowania, narzekać stale na coś; zrzędzić, utyskiwać' }\end{array}$ \\
\hline 53. & gędzić & 'grać na harfie, dudach; brzdąkać, przygrywać, śpiewać' \\
\hline 54. & gorącować się & 'gorączkować się, niecierpliwić się, unosić się, zżymać się' \\
\hline 55. & hajdamaczyć & 'postępować jak hajdamak; awanturować się' \\
\hline 56. & indukować & $\begin{array}{l}\text { 'prowadzić, kontynuować coś, np. mowę; popierać, podtrzymywać coś, } \\
\text { np. oskarżenie w sądzie' }\end{array}$ \\
\hline 57. & inkulpować & 'przypisywać komuś winę, oskarżać' \\
\hline 58. & instygować 1 & 'inspirować, gorliwie coś doradzać, podjudzać do czegoś' \\
\hline 59. & instygować 2 & 'oskarżać, skarżyć przed sądem' \\
\hline 60. & insultować & 'obrzucać obelgami, znieważać' \\
\hline 61. & introdukować się & 'mieszać się, wdawać się, wtrącać się’ \\
\hline 62. & iścić 3 & 'głosić, twierdzić, zapewniać' \\
\hline 63. & jękać 2 & p. jąkać ('mówić coś niewyraźnie, nieskładnie, niepłynnie; bąkać’) \\
\hline 64. & jurzyć & 'pobudzać do gniewu, jątrzyć; waśnić, podburzać' \\
\hline 65. & jurzyć się 1 & 'unosić się gniewem, srożyć się’ \\
\hline 66. & justyfikować & 'usprawiedliwiać, thumaczyć' \\
\hline 67. & juszyć się 2 & 'złościć się; unosić się gniewem' \\
\hline 68. & kalumniować & 'rzucać kalumnie na kogoś; szkalować, spotwarzać' \\
\hline 69. & kasać się 1 & 'stawiać się, odpowiadać zuchwale' \\
\hline 70. & kazywać & 'często albo od czasu do czasu wygłaszać kazania; miewać kazania' \\
\hline 71. & kierleszować & $\begin{array}{l}\text { 'śpiewać litanie, pieśni z powtarzającym się przyśpiewem: kyrie } \\
\text { eleison' }\end{array}$ \\
\hline
\end{tabular}




\begin{tabular}{|c|c|c|}
\hline Lp. & Forma hasłowa & Znaczenie \\
\hline 72. & klarygować & p. klarować w zn. 2 (pot. 'wyjaśniać, thumaczyć') \\
\hline 73. & kląć 1 & 'rzucać klątwę, wyklinać' \\
\hline 74. & kląć 2 & 'zaklinać' \\
\hline 75. & klątwić & 'przeklinać kogoś, złorzeczyć komuś' \\
\hline 76. & klimkować & $\begin{array}{l}\text { równoznaczne z wyrażeniem: klimkiem rzucać... p. klimek (tu: daw. } \\
\text { tylko w wyrażeniach: klimkiem rzucać, bawić się ‘tumanić, zmyślać, } \\
\text { mówić wykrętnie, mówić nieprawdę; klimkować’ etymologia <zdr. } \\
\text { imię Klemens; od listów papieża Klemensa I („klimków”), które } \\
\text { różnowiercy w Polsce w. XVI i XVII uważali za sfałszowane>) }\end{array}$ \\
\hline 77. & kołować & 'prowadzić obrady, zjeżdżać się na koło; sejmikować' \\
\hline 78. & kondemnować & 'skazywać wyrokiem zaocznym, potępiać' \\
\hline 79. & konfirmować & 'potwierdzać, zatwierdzać, uznawać' \\
\hline 80. & konkludować 2 & 'omawiać' \\
\hline 81. & konsolować & 'pocieszać' \\
\hline 82. & kontestować & 'zaprzeczać czemuś, kwestionować coś, podawać w wątpliwość' \\
\hline 83. & konwinkować & 'dowodzić, przekonywać' \\
\hline 84. & konwokować & 'zwoływać, zbierać' \\
\hline 85. & kpać & 'krzyczeć na kogoś, łajać, wymyślać (od kpów)’ \\
\hline 86. & krzeczeć & 'wydawać skrzypiący, skrzeczący głos’ \\
\hline 87. & lajać 2 & 'urągać czemuś, narzekać na coś, przeklinać coś’ \\
\hline 88. & majaczyć 2 & $\begin{array}{l}\text { 'mamić, zwodzić, mówić niejasno, wykrętnie, mydlić komuś oczy; } \\
\text { wykręcać się od czegoś obietnicami, ociągać się, zwlekać' }\end{array}$ \\
\hline 89. & manifestować 1 & 'wnosić protest; protestować; składać manifest do władz sądowych’ \\
\hline 90. & $\begin{array}{l}\text { manifestować się } \\
1\end{array}$ & $\begin{array}{l}\text { p. manifestować w zn. } 2 \text { 'wnosić protest; protestować; składać manifest } \\
\text { do władz sądowych' }\end{array}$ \\
\hline 91. & $\begin{array}{l}\text { manifestować się } \\
2\end{array}$ & $\begin{array}{l}\text { 'opowiadać się za kimś, za czymś, ujmować się za kimś, upominać się } \\
\text { o coś' }\end{array}$ \\
\hline 92. & markotać 1 & $\begin{array}{l}\text { p. mamrotać (zn. 1) 'mówić półgłosem, niewyraźnie, niezrozumiale; } \\
\text { mruczeć pod nosem' }\end{array}$ \\
\hline 93. & matać 2 & $\begin{array}{l}\text { p. mataczyć 'posługiwać się matactwami, robić intrygi; wichrzyć, } \\
\text { oszukiwać, kręcić' }\end{array}$ \\
\hline 94. & mędrować & $\begin{array}{l}\text { p. mądrować: tu: rzad. p. mędrkować: 'udawać mądrego; popisywać się } \\
\text { wątpliwą mądrością; mądrzyć się, wymądrzać się' }\end{array}$ \\
\hline 95. & mikać & 'ryczeć (o bydle); ryczeć jak bydło’ \\
\hline 96. & milić się & 'starać się komuś przypodobać; przymilać się’ \\
\hline 97. & modlić & 'prosić w modlitwie; błagać' \\
\hline 98. & modlić się & 'prosić, upraszać, dopraszać się' \\
\hline 99. & modyfikować & 'łagodzić, powściągać' \\
\hline 100. & mościać & p. II mościć: ‘tytułować miłościwym panem, mości panem, mościem’ \\
\hline
\end{tabular}




\begin{tabular}{|c|c|c|}
\hline Lp. & Forma hasłowa & Znaczenie \\
\hline 101. & musić & 'wywierać na kogoś nacisk, stosować przymus; zmuszać, przymuszać' \\
\hline 102. & nadarzyć się & 'strona zwrotna czas. nadarzyć: zaproponować, nastręczyć siebie’ \\
\hline 103. & nadgłosić & 'zgłosić się' \\
\hline 104. & nadstawiać się 4 & 'pysznić się, popisywać się czymś, np. strojem' \\
\hline 105. & nadstawiać się 5 & 'przeciwstawiać się’ \\
\hline 106. & nadsunąć & 'poddać coś komuś (np. myśl, projekt); nastręczyć, nasunąć' \\
\hline 107. & nafortować & 'wywrzeć wpływ na kogoś, zmusić do czegoś; podjudzić, podbechtać' \\
\hline 108. & nagabać & $\begin{array}{l}\text { p. nagabywać ('zwracać się do kogoś z żądaniem lub prośbą o coś; } \\
\text { zaczepiać, napastować, niepokoić kogoś /tu: nagabywać - nagabnąć/) }\end{array}$ \\
\hline 109. & nagadnąć & 'zagadnąć, zapytać' \\
\hline 110. & nagędzić & 'dużo, długo gędzić' \\
\hline 111. & naigrawać & $\begin{array}{l}\text { p. naigrawać się ('odnosić się do kogoś, czegoś z szyderstwem, } \\
\text { drwinami, lekceważeniem; urągać, szydzić, kpić, naśmiewać się, } \\
\text { natrząsać się (dziś: naigrawać się z kogoś, czegoś; dawniej: naigrawać } \\
\text { się komuś, czemuś)') }\end{array}$ \\
\hline 112. & najdować 2 & $\begin{array}{l}\text { 'widzieć, upatrywać coś w czymś, dopatrywać się czegoś, być jakiegoś } \\
\text { zdania o czymś; sądzić, osądzać, oceniać, dostrzegać' }\end{array}$ \\
\hline 113. & nakpać się & $\begin{array}{l}\text { 'nawymyślać sobie wzajemnie, niekiedy: nawymyślać komuś do woli, } \\
\text { do syta (od kpów)' }\end{array}$ \\
\hline 114. & nalec 1 & $\begin{array}{l}\text { p. nalegać (zn. 1: 'natarczywie, uparcie chcieć czegoś od kogoś; } \\
\text { nastawać, żądać, domagać się, dopominać się') }\end{array}$ \\
\hline 115. & namienić & 'uczynić wzmiankę, nadmienić, wspomnieć, wymienić' \\
\hline 116. & namknąć 2 & 'napomknąć, wspomnieć o czymś' \\
\hline 117. & napowiadać & 'dużo powiedzieć; naopowiadać' \\
\hline 118. & naprawiać & $\begin{array}{l}\text { 'namawiać kogoś do zrobienia, popełnienia czegoś, do działania na } \\
\text { czyjąś szkodę; podmawiać, poduszczać, podżegać; nasyłać' }\end{array}$ \\
\hline 119. & narągać się & 'wyśmiewać się, szydzić z kogoś; urągać' \\
\hline 120. & nawołać 1 & $\begin{array}{l}\text { 'przywołać, przyzwać kogoś, coś do siebie, na dane miejsce; zawołać, } \\
\text { zwołać' }\end{array}$ \\
\hline 121. & nieważyć & 'wyrządzić zniewagę, ubliżać; obrażać (kogoś, coś), znieważać' \\
\hline 122. & nominować 2 & 'nazywać kogoś' \\
\hline
\end{tabular}

W tabeli 2. znajdują się jednostki leksykalne opatrzone w SJPD kwalifikatorem przestarz., co oznacza, że uznano je za nieco mniej archaiczne. Jest to 87 jednostek leksykalnych, które nie mają innego typu kwalifikatorów. Kwestia granicy pomiędzy jednostkami określonymi jako dawne i przestarzałe, jest oczywiście niewyrazista i nieostra, zdaje jednak sprawę z oceny leksyki dokonanej przez redaktorów SJPD (por. SJPD: XL). 
Tabela 2. Verba dicendi określone w SJPD jako przestarzałe

\begin{tabular}{|c|c|c|}
\hline Lp. & Forma hasłowa & Znaczenie \\
\hline 1. & admirować & 'podziwiać, uwielbiać' \\
\hline 2. & adresować & 'kierować, zwracać, stosować, odnosić do kogo' \\
\hline 3. & alegować & 'podawać jako dowód, przytaczać, powoływać się na coś' \\
\hline 4. & ambarasować & $\begin{array}{l}\text { 'przysparzać trudności, zmartwień, sprawiać kłopot; wprawiać } \\
\text { w zakłopotanie' }\end{array}$ \\
\hline 5. & animować & 'ożywiać, zabawiać; zagrzewać, podniecać, zachęcać' \\
\hline 6. & bajać & 'opowiadać baśnie lub bajki; snuć opowieść, opowiadać, prawić o czymś’ \\
\hline 7. & bajać & 'opowiadać niestworzone rzeczy, pleść bez sensu, bajdurzyć, ględzić' \\
\hline 8. & barłożyć & 'bajać, pleść, bajdurzyć, bzdurzyć' \\
\hline 9. & brzechać & 'szczekać, ujadać; mówić na wiatr, gadać bez celu’ \\
\hline 10. & bufonować & 'zachowywać się jak bufon, błaznować, pysznić się, przechwalać się' \\
\hline 11. & bywać & 'forma powitania: witaj, przybywaj' \\
\hline 12. & czernić się & 'wzajemnie siebie obmawiać, szkalować, oczerniać' \\
\hline 13. & desperować & 'rozpaczać, tracić nadzieję; lamentować' \\
\hline 14. & dialogować & 'rozmawiać' \\
\hline 15. & dopytać & ‘wypytując się znaleźć coś lub kogoś; doszukać się czegoś’ \\
\hline 16. & dworować 1 & 'drwić, kpić, wyśmiewać się, szydzić z kogoś, z czegoś’ \\
\hline 17. & dyfamować & 'zniesławiać, oskarżać, oczerniać' \\
\hline 18. & dysertować & 'rozprawiać, dyskutować' \\
\hline 19. & dziękczynić & 'składać podziękowanie, dziękować' \\
\hline 20. & efektować & 'wywierać efekt, dążyć do wywołania efektu; przesadzać' \\
\hline 21. & egzagerować & $\begin{array}{l}\text { 'przypisywać czemuś zbyt wielkie rozmiary, znaczenie; zmyślać, } \\
\text { przesadzać' }\end{array}$ \\
\hline 22. & egzaltować & 'wywyższać, wysławiać; wprawiać w stan egzaltacji' \\
\hline 23. & ekscytować & $\begin{array}{l}\text { 'pobudzać, zachęcać do wykonania jakieś czynności; przynaglać, } \\
\text { zalecać coś, przypominać' }\end{array}$ \\
\hline 24. & eksplikować & 'czynić coś zrozumiałym, jasnym; wyjaśniać, tłumaczyć, uzasadniać' \\
\hline 25. & erygować 2 & ‘zamianować, przemianować (na coś lepszego, wyższego)’ \\
\hline 26. & faktorzyć 2 & p. faktorzyć (zn. 2: 'wstawiać się, przemawiać za kimś’) \\
\hline 27. & ferować & $\begin{array}{l}\text { 'wydawać, zatwierdzać; orzekać, postanawiać (dziś tylko w wyrażeniu: } \\
\text { ferować wyrok)' }\end{array}$ \\
\hline 28. & garlować & $\begin{array}{l}\text { p. gardłować (w przykładach w zn. 1) zn. 1: 'przemawiać z przejęciem, } \\
\text { z ożywieniem; rozprawiać, mówić dużo i głośno; zdzierać gardło; } \\
\text { krzyczeć' }\end{array}$ \\
\hline 29. & gawędzić & 'opowiadać, bajać, prawić, pleść' \\
\hline 30. & gęślić & 'grać na gęślach; opiewać coś' \\
\hline
\end{tabular}




\begin{tabular}{|c|c|c|}
\hline Lp. & Forma hasłowa & Znaczenie \\
\hline 31. & głosić 1 & 'komunikować coś za pomocą głosu; mówić, wygłaszać' \\
\hline 32. & glosić 2 & 'sławić' \\
\hline 33. & głosić się & 'rozpowiadać, że się jest czymś (kimś), twierdzić coś o sobie’ \\
\hline 34. & gwarzyć & 'czynić gwar, hałasować' \\
\hline 35. & hałasować & 'robić zamieszanie, awantury, protestować' \\
\hline 36. & halasować się & $\begin{array}{l}\text { forma wzmocniona czas. hałasować (tylko w zn. 2: 'robić zamieszanie, } \\
\text { awantury, protestować') }\end{array}$ \\
\hline 37. & inkwirować & 'prowadzić śledztwo, przesłuchiwać, wypytywać, badać' \\
\hline 38. & inwitować & 'zapraszać, wzywać' \\
\hline 39. & jendyczyć się & $\begin{array}{l}\text { p. indyczyć się (żart. pouf. 'okazywać gniew, złość z błahych powodów, } \\
\text { zwykle w sposób komiczny; czupurzyć się, puszyć się, nadymać się') }\end{array}$ \\
\hline 40. & kaprysić się & $\begin{array}{l}\text { forma wzmocniona czas. kaprysić ('mieć kaprysy, dziwactwa, być } \\
\text { w złym humorze bez widocznego powodu, grymasić') }\end{array}$ \\
\hline 41. & kazać & tylko ndk ('wygłaszać, prawić kazanie; głosić coś z ambony, obwieszczać') \\
\hline 42. & kazić 2 & 'demoralizować, gorszyć; przynosić ujmę, hańbić’ \\
\hline 43. & każolować & 'schlebiać komuś; troskliwie się opiekować kimś; głaskać, pieścić' \\
\hline 44. & kiepkować & 'stroić żarty, kpić, dowcipkować' \\
\hline 45. & klektać 2 & $\begin{array}{l}\text { p. klekotać w zn. } 3 \text { (pot. 'mówić dużo i głośno; trajkotać, paplać, } \\
\text { klepać) }\end{array}$ \\
\hline 46. & kłamać 2 & 'przeczyć, zaprzeczyć czemuś, nie być w zgodzie z czymś' \\
\hline 47. & kłaść & 'uważać, traktować, podawać jako przyczynę’ \\
\hline 48. & kłonić & 'nakłaniać, namawiać, zmuszać' \\
\hline 49. & komplimentować & p. komplementować ('prawić komplementy; chwalić') \\
\hline 50. & $\begin{array}{l}\text { komplimento- } \\
\text { wać się }\end{array}$ & $\begin{array}{l}\text { p. komplementować się w zn. } 1 \text { ('komplementować siebie wzajemnie, } \\
\text { obsypywać się wzajemnie komplementami') }\end{array}$ \\
\hline 51. & komponować & 'zmyślać, blagować, fantazjować' \\
\hline 52. & kondolować & 'składać kondolencję’ \\
\hline 53. & konkludować 1 & $\begin{array}{l}\text { 'podsumowywać np. wypowiedź, formułować ostateczne wnioski, } \\
\text { wnioskować' }\end{array}$ \\
\hline 54. & kontrować & $\begin{array}{l}\text { 'być kontra, czyli przeciw czemuś lub komuś; przeczyć, sprzeciwiać się, } \\
\text { oponować' }\end{array}$ \\
\hline 55. & kontrować się & 'przeczyć sobie wzajemnie, być w niezgodzie' \\
\hline 56. & manić 1 & p. mamić w zn. 1 'działać łudząco; bałamucić, zwodzić, tumanić' \\
\hline 57. & manić 2 & p. mamić w zn. 2 'wabić, nęcić, pociągać' \\
\hline 58. & markocić & 'być markotnym, zmartwionym, niezadowolonym; narzekać, smucić się' \\
\hline 59. & mataczyć & 'posługiwać się matactwami, robić intrygi; wichrzyć, oszukiwać, kręcić' \\
\hline 60. & mianować & 'nadawać miano; nazywać' \\
\hline 61. & mianować się & 'być mianowanym, być nazywanym' \\
\hline
\end{tabular}




\begin{tabular}{|c|c|c|}
\hline Lp. & Forma hasłowa & Znaczenie \\
\hline 62. & mienić I & $\begin{array}{l}\text { 'nadawać miano, nazywać kogoś lub coś; tytułować; głosić coś o kimś } \\
\text { lub czymś; uważać, mieć kogoś lub coś za coś’ }\end{array}$ \\
\hline 63. & mieszać & \begin{tabular}{|l} 
'wprowadzać zamieszanie, dysharmonię; zakłócać, mącić (dziś żywe \\
w zwrotach: mieszać komu w głowie, mieszać komu myśli, mieszać szyki)'
\end{tabular} \\
\hline 64. & mięszać 5 & $\begin{array}{l}\text { p. mieszać w zn. } 6 \text { 'wprowadzać zamieszanie, dysharmonię; zakłócać, } \\
\text { mącić (dziś żywe w zwrotach: mieszać komu w głowie, mieszać komu } \\
\text { myśli, mieszać szyki)' }\end{array}$ \\
\hline 65. & moderować 1 & 'łagodzić, powściągać, powstrzymywać, uspokajać' \\
\hline 66. & moderować się & 'powściągać się, powstrzymywać się od czegoś; hamować się' \\
\hline 67. & momotać & 'mówić niewyraźnie, niezrozumiale; bełkotać' \\
\hline 68. & monitować & $\begin{array}{l}\text { 'karcić kogoś za niewłaściwe postępowanie, zachowanie się; strofować, } \\
\text { napominać' }\end{array}$ \\
\hline 69. & mydłkować & 'używać wykrętów; wyłgiwać się, wykręcać się, wykpiwać się’ \\
\hline 70. & nabechtać & $\begin{array}{l}\text { 'namówić kogoś do czegoś, poduszczyć kogoś przeciwko komuś; } \\
\text { podbechtać, podburzyć, podjudzić' }\end{array}$ \\
\hline 71. & nabiedować się & 'długo, dużo użalać się, lamentować; nażalić się' \\
\hline 72. & nadać 1 & 'pomóc, poradzić; przydać się' \\
\hline 73. & nadrwinkować & $\begin{array}{l}\text { p. nadrwić (wypowiedzieć pod czyimś adresem wiele drwiących uwag; } \\
\text { nakpić, naszydzić)' }\end{array}$ \\
\hline 74. & nadstawiać się 1 & $\begin{array}{l}\text { 'narzucać się komuś ze swoim towarzystwem, ze swoją osobą, nadskaki- } \\
\text { wać komuś' }\end{array}$ \\
\hline 75. & naganiać II 1 & 'osądzać coś ujemnie, napominać kogoś; robić komuś wyrzuty; ganić' \\
\hline 76. & nalżyć & 'wykonać czynność lżenia wielokrotnie, nawymyślać komuś' \\
\hline 77. & nałajać & 'zganić ostro, nawymyślać, zwymyślać' \\
\hline 78. & nałajać się 1 & 'długo, ostro wymyślać, ganić; zwymyślać do woli’ \\
\hline 79. & nałajać się 2 & 'nawzajem, wzajemnie sobie nawymyślać' \\
\hline 80. & napytać & 'pytając dowiedzieć się o czymś, znaleźć kogoś, coś' \\
\hline 81. & naradzać 1 & $\begin{array}{l}\text { p. naradzać się ('porozumiewać się w jakiejś sprawie; zasięgając } \\
\text { wzajemnie swojej opinii, wspólnie roztrząsać coś (dziś: naradzać się nad } \\
\text { czymś, dawniej także: o czymś)') }\end{array}$ \\
\hline 82. & naradzać 2 & 'dawać rady w jakiejś sprawie; doradzać coś' \\
\hline 83. & nasadzić 1 & $\begin{array}{l}\text { 'namówić, nasłać kogoś przeciw komuś; polecić komuś zastawienie } \\
\text { zasadzki na kogoś; dawniej także; podburzyć, podjudzić przeciw komuś' }\end{array}$ \\
\hline 84. & nastawać 1 & 'powstawać, występować przeciw czemuś lub komuś; ganić, potępiać' \\
\hline 85. & natrącać 1 & $\begin{array}{l}\text { 'czynić wzmiankę o czymś, dotykać jakiegoś tematu; napomykać, } \\
\text { nadmieniać, wspominać' }\end{array}$ \\
\hline 86. & natrącać 2 & $\begin{array}{l}\text { 'poddawać, podsuwać, nasuwać myśli, rady, zamiary itp.; narzucać } \\
\text { komuś czyjąś osobę' }\end{array}$ \\
\hline 87. & negocjować & $\begin{array}{l}\text { 'prowadzić układy, pertraktacje, rokowania; umawiać się o coś, } \\
\text { omawiać, układać coś' }\end{array}$ \\
\hline
\end{tabular}


Poza materiałem leksykalnym przedstawionym w obu tabelach zwraca uwagę grupa jednostek opatrzonych oprócz kwalifikatorów chronologicznych, także innego typu określeniami. Zbiór ten wśród czasowników mówienia liczy 25 jednostek. Jest to zapewne związane ze sposobem kwalifikowania słownictwa w SJPD, daje jednak pewną informację - jak wspomniałam powyżej - o węższym zakresie występowania wymienionych jednostek niż w wypadku wszystkich jednostek przedstawionych $\mathrm{w}$ tabelach 1 . i 2 . Wszystkie czasowniki mówienia stanowiące podstawę badania zostały uznane za wychodzące $\mathrm{z}$ użycia w połowie XX wieku, a więc po zakończeniu doby nowopolskiej w Klemensiewiczowskim rozumieniu. Słownictwo opatrzone informacjami także innymi niż dotyczące chronologii stanowi zdecydowaną mniejszość ( 25 jednostek w stosunku do 209 jedynie z kwalifikatorem chronologicznym). Wydaje się jednak, ze względu na te właśnie dodatkowe wskazówki leksykografów, że jest ono najbardziej interesujące. Losy tych jednostek leksykalnych są przedstawione w artykule. Czasowniki mówienia zawierające w SJPD informację o chronologii, a także uwzględnione w słowniku kwalifikatory zostały zaprezentowane w tabeli 3 .

Tabela 3. Verba dicendi zawierające w SJPD dodatkowe kwalifikatory (oprócz chronologicznych)

\begin{tabular}{|c|c|c|c|c|}
\hline Lp. & Forma hasłowa & $\begin{array}{l}\text { Kwalifikator } \\
\text { chronologiczny }\end{array}$ & \begin{tabular}{c|} 
Pozostałe \\
kwalifikatory
\end{tabular} & Znaczenie \\
\hline 1. & aplaudować & daw. & przen. & $\begin{array}{l}\text { 'przyklaskiwać, pochwalać, wyrażać } \\
\text { uznanie' }\end{array}$ \\
\hline 2. & gadulić & daw. & rzad. & 'gadać, paplać' \\
\hline 3. & instynktować & daw. & rzad. & 'dać polecenie, rozkazywać' \\
\hline 4. & markotać 2 & daw. & rzad. & $\begin{array}{l}\text { p. mamrotać (zn. 2) 'gderać, zrzędzić; } \\
\text { burczeć gniewnie' }\end{array}$ \\
\hline 5. & dekurażować & przestarz. & rzad. & $\begin{array}{l}\text { 'odbierać komuś odwagę, energię; } \\
\text { zniechęcać, zrażać kogoś' }\end{array}$ \\
\hline 6. & fajnować 2 & przestarz. & żart. & 'kłamać, oszukiwać' \\
\hline 7. & flecić 2 & przestarz. & rzad.przen. & $\begin{array}{l}\text { 'grać, pisać, wypowiadać się rzewnie, } \\
\text { sentymentalnie, smętnie' }\end{array}$ \\
\hline 8. & kolorować & przestarz. & przen. & $\begin{array}{l}\text { ‘upiększać, urozmaicać' (por. koloryzo- } \\
\text { wać w zn. 1: 'przesadzać, przejaskrawiać } \\
\text { w opowiadaniach w relacjach; blagować') }\end{array}$ \\
\hline 9. & konwersować & przestarz. & dziś książk. & $\begin{array}{l}\text { 'prowadzić rozmowę towarzyską, } \\
\text { rozmawiać z kimś' }\end{array}$ \\
\hline 10. & malować & przestarz. & przen. & 'wyrażać, uzewnętrzniać' \\
\hline 11. & mazać & przestarz. & przen. & $\begin{array}{l}\text { zn. 1. 'powlekać, pociągać coś, smarować, } \\
\text { namaszczać, brudzić, walać jakąś } \\
\text { substancją mazistą', tu: przen. przestarz. } \\
\text { 'kalać, plugawić, szkalować, bezcześcić' }\end{array}$ \\
\hline
\end{tabular}




\begin{tabular}{|c|c|c|c|c|}
\hline Lp. & Forma hasłowa & $\begin{array}{c}\text { Kwalifikator } \\
\text { chronologiczny }\end{array}$ & $\begin{array}{c}\text { Pozostałe } \\
\text { kwalifikatory }\end{array}$ & Znaczenie \\
\hline 12. & molestować 2 & przestarz. & rzad. & $\begin{array}{l}\text { nieprzechodnio 'biadać, narzekać, } \\
\text { ubolewać' }\end{array}$ \\
\hline 13. & mościć II & przestarz. & zwykle żart. & $\begin{array}{l}\text { 'tytułować miłościwym panem, mości } \\
\text { panem, mościem' }\end{array}$ \\
\hline 14. & naklektać & przestarz. & pot. & 'nagadać; napaplać' \\
\hline 15. & nawieszczyć & przestarz. & $\begin{array}{l}\text { dziś podn. a. } \\
\text { żart. }\end{array}$ & $\begin{array}{l}\text { 'wypowiedzieć wiele przepowiedni, } \\
\text { proroctw, wróżb' }\end{array}$ \\
\hline 16. & mniemać & $\begin{array}{l}\text { stopniowo } \\
\text { wychodzace z } \\
\text { użycia }\end{array}$ & książk. & $\begin{array}{l}\text { 'być zdania, uważać, sądzić, przypusz- } \\
\text { czać' }\end{array}$ \\
\hline 17. & bundiuczyć się & daw. & reg. wsch. & $\begin{array}{l}\text { p. buńczuczyć się 'zachowywać się } \\
\text { buńczucznie; pysznić się, srożyć się, } \\
\text { gniewać się' }\end{array}$ \\
\hline 18. & $\begin{array}{l}\text { bundziuczyć } \\
\text { się }\end{array}$ & daw. & reg. wsch. & $\begin{array}{l}\text { p. buńczuczyć się 'zachowywać się } \\
\text { buńczucznie; pysznić się, srożyć się, } \\
\text { gniewać się' }\end{array}$ \\
\hline 19. & buńdiuczyć się & daw. & reg. wsch. & $\begin{array}{l}\text { p. buńczuczyć się 'zachowywać się } \\
\text { buńczucznie; pysznić się, srożyć się, } \\
\text { gniewać się' }\end{array}$ \\
\hline 20. & cudować & daw. & $d z i s ́ g w$. & $\begin{array}{l}\text { 'grymasić, kaprysić, dziwić się, postępo- } \\
\text { wać dziwacznie; wydziwiać' }\end{array}$ \\
\hline 21. & halasić & daw. & $d z i s ́ g w$. & $\begin{array}{l}\text { p. hałasować w zn. } 1 \text { ('robić hałas, zgiełk, } \\
\text { głośno się zachowywać; wrzeszczeć, } \\
\text { stukać') }\end{array}$ \\
\hline 22. & krzykać & daw. & dziś gw. & 'krzyczeć, pokrzykiwać, hukać' \\
\hline 23. & mrukać & daw. & dziś reg. & $\begin{array}{l}\text { p. mruczeć (w przykładzie w zn. 2): } \\
\text { 'mówić, śpiewać niewyraźnie, cicho; } \\
\text { mamrotać; wydawać nie artykułowane, } \\
\text { niskie dźwięki naśladujące głos niektó- } \\
\text { rych zwierząt, np. kota' (sic!) }\end{array}$ \\
\hline 24. & gębować & przestarz. & $d z i s ́ g w$. & $\begin{array}{l}\text { 'arogancko odpowiadać; wymyślać } \\
\text { komuś, pyskować; rozprawiać głośno, } \\
\text { gardłować' }\end{array}$ \\
\hline 25. & nakazać & przestarz. & reg. & 'polecić, zawiadomić' \\
\hline
\end{tabular}

W powyższej tabeli zaprezentowane zostały wszystkie czasowniki wybrane jako verba dicendi spośród jednostek leksykalnych wychodzących z użycia w dobie nowopolskiej opatrzone w SJPD dodatkowymi kwalifikatorami oprócz chronologicznych. Zostały one uporządkowane według kwalifikatorów: w pierwszej części tabeli te, które miały kwalifikator odnoszący się do frekwencji lub stylistycznej odmiany polszczyzny, a następnie związane z odmianami terytorialnymi (oddzielnie dawne, oddzielnie przestarzałe i wychodzace z użycia). Informacje na temat kwalifikatorów znajdują się w dalszej części artykułu. 
Nie wszystkie zgromadzone $\mathrm{w}$ tabeli jednostki leksykalne podlegały przekształceniom semantycznym w dobie nowopolskiej ( 8 znaczeń nie zmieniło się, 3 nie zostały uwzględnione w żadnym ze słowników oprócz SJPD). Obserwacja znaczeń w źródłach leksykograficznych doby nowopolskiej pokazuje, że w tym okresie niektóre ze znaczeń nie podlegały już modyfikacji, dotyczy to czasowników: aplaudować, bundiuczyć się, bundziuczyć się oraz buńdiuczyć się (w SJPD potraktowane jako osobne hasła), hałasić, krzykać, mniemać, naklektać. Różnego typu przekształcenia znaczeniowe dotyczyły jednak większości wymienionych jednostek (14).

Analiza materiału obejmuje informacje na temat notowania leksyki w źródłach leksykograficznych.

\section{Analiza materiału}

Osiem jednostek leksykalnych wychodzących z użycia zostało uwzględnionych w źródłach leksykograficznych odnoszących się do doby nowopolskiej w tym samym znaczeniu, nie nastąpiły więc w odniesieniu do nich w tym okresie żadne zmiany znaczeniowe.

\section{BUNDIUCZYĆ SIĘ, BUNDZIUCZYĆ SIĘ, BUŃDIUCZYĆ SIE}

Są to m.in. jednostki: bundiuczyć się, bundziuczyć się oraz buńdiuczyć się wszystkie trzy formy są wariantami fonetycznymi lub nawet tylko ortograficznymi tego samego wyrazu, który oznacza tyle co buńczuczyć się: 'zachowywać się buńczucznie; pysznić się, srożyć się, gniewać się’, określone w SJPD jako regionalizmy wschodnie. Czasownik ten został zaliczony do czasowników mówienia z pewnymi zastrzeżeniami, ponieważ źródła leksykograficzne nie pozwalają stwierdzić, czy czynność, którą nazywa, może się wiązać z komunikatem słownym, czy też wystarczające są w odniesieniu do niej pozawerbalne formy komunikacji.

\section{HALASIĆ}

W wypadku czasownika hatasić interesująca jest kwestia formalna, nie zaś znaczeniowa. Przez dłuższy okres funkcjonowały jednocześnie dwie formy hałasić i hałasować. W SL oraz SWil obie zostały zdefiniowane łącznie. W SL pod hasłem hałas podane są oba czasowniki hałasić, hałasować w znaczeniu 'hałasu, krzyku, zgiełku narobić', przy czym forma hałasić wymieniona jest jako pierwsza, do niej też odnosi się więcej przykładów. SWil również notuje formę hałasić na pierwszym miejscu, przykłady odnoszą się natomiast tylko do czasownika $h a-$ tasować: Proszę cię, nie hałasuj. Hałasować na kogo. Hałasować o co. Hałasuje o lada rzecz. Czego v. co on tak hałasuje?. W SW przy haśle hatasić znajduje się kwalifikator † (co oznacza wyraz staropolski) oraz odesłanie do hałasować, więc znaczenie tych dwóch wyrazów można uznać za synonimiczne, ale formę hałasić 
za rzadziej i dawniej używaną, słownik odnotowuje jednak dwa przykłady: Ów skrzydlaty piorun, co hałasit wściekle. Przyb. oraz $\mathrm{w}$ zwrocie $\dagger$ hałasić kogo 'przestraszyć kogo hałasem' z przykładem Wedrze ś. zbrojno w obóz i tak ich hatasi, że do szyku przyjść nie mogli. Pot. SJPD odnotowuje czasownik hałasić z kwalifikatorem daw. dziś gw. ale z odesłaniem do czasownika hałasować w zn. 1: 'robić hałas, zgiełk, głośno się zachowywać; wrzeszczeć, stukać' z przykładami: Koza przycichła, nie hałasi, bo głodna. Świerszcz. 31, 1951. W lochu hałasi licho!... Orle karpacki! zajrzyj w te lochy, nie pogrzebione tam jęcza prochy, na złocie czart siedzi na dnie. WAS. E. Poezje 192. W połowie XX wieku był to zatem czasownik o zasięgu ograniczonym terytorialnie. USJP - co w tej sytuacji zrozumiałe - nie notuje już formy hałasić. Przykład ten potwierdza, że jeżeli w języku funkcjonują dwie jednostki różne formalnie, ale tożsame znaczeniowo, i nie nastąpi w wypadku obu form choćby niewielkie zróżnicowanie znaczeniowe, wówczas jedna $\mathrm{z}$ nich jako niepotrzebna w języku (czy też zależnie od ujęcia: w systemie) - zanika. Można to powiązać z działaniem tendencji do ekonomizacji.

\section{KRZYKAĆ}

Podobna sytuacja wariantywności formantów dotyczy czasownika krzykać. SL odnotowuje trzy formy: krzyczeć oznaczoną jako $n d k$, $k r z y k n a c ́ c-i d n t l$. i $k r z y$ $k a c ́$ - kontyn., wszystkie trzy formy ilustrowane są przykładami. SWil odnotowuje krzykać jako scz. nd. (słowo czasownikowe niedokonane) w znaczeniu 'wydawać krzyki, wrzaski', przy czym definicja nie mówi o tym, czy czasownik ten może być użyty jako czasownik mówienia, a jedyny podany przykład tego również nie potwierdza, odnosi się bowiem do zwierzęcia: Odyniec krzyka. Czasowniki krzyczeć i krzyknać według SWil bez wątpienia odnoszą się do czynności mówienia, pierwsze określone jest jako $s c z$. $n d$., drugie $-s c z$. jednt. W SW przy czasowniku krzykać znajdują się dwa kwalifikatory: raz słowo podane jest z oznaczeniem $\uparrow$, a obok drugi raz [krzykać] w nawiasach kwadratowych, które świadczą o występowaniu czasownika w gwarach, znajduje się tu także odesłanie do słowa krzyknać oraz ilustracja materiałowa. Przykłady zamieszczone w SW to: Krzykam do potrzeby. Kn., [Pawik poleciat do domu krzykajacy]. Chtopak pędzi a krzyka, że aż kłada ś. szkapki. Len. Przy słowie krzyczeć znajduje się w SW odesłanie do krzyknać, czyli to ta forma została uznana za główną. W SJPD znajduje się tylko jedno znaczenie słowa krzykać 'krzyczeć, pokrzykiwać, hukać'. Przykładem niewątpliwie odnoszącym się do czynności mówienia z SJPD jest: Ten krzyka, że u niego darmo stoję, ten, że mi jeść więcej nie da. TREMB. Listy I, 59. USJP nie notuje tej formy czasownika, znajduje się w nim natomiast hasło $k r z y k n a c c ́$ - krzyczeć. Znów zatem wniosek jest taki, że z trzech funkcjonujących form przetrwały do dziś w języku ogólnym tylko dwie.

\section{NAKLEKTAĆ}

SL notuje czasownik naklektać w znaczeniu 'dosyć wiele poklektać; klektaniem go namówić’ z przykładem: U paniąt lagodna mowa naklektanych, zboże 
bardzo tanie kupowali. Kosz. Lor. 53 b. Jest to więc - jak się wydaje - to samo znaczenie, które zostało wybrane jako daw. dziś gw. z SJPD 'nagadać, napaplać'. Interesujące jest to, że w SWil wyodrębniono więcej znaczeń szczegółowych, o różnej rekcji: 1. czego 'nagadać, nabajać'. Naklektać gtupstw. 2. co 'nieskończonem gadaniem odurzyć'. Naklektała mi głowę. 3. kogo. posp. 'gadatliwością kogo namówić, zwieść'. Naklektała go do tej podróży, 4. komu: Naklektać komu do uszu; też: Naklektała mi głowę. W SW również znalazły się trzy znaczenia (1. 'klekcząc, nagadać, nabajać'; 2. N. komu głowę = 'klekcząc, nabić paplaniną'; 3. $\operatorname{kogo}=$ 'odurzyć klektaniem'), nie ma tu natomiast odnotowanego w SL oraz SWil znaczenia 'namówić kogoś klektaniem'. W SJPD odnotowano tylko jedno znaczenie ogólne 'nagadać, napaplać', ale już jako dawne i w XX wieku ograniczone do gwar. Formy klektać i klekotać odnotowały zarówno SL, SWil, jak i SW (przen.) także - oprócz innych znaczeń - jako czasowniki mówienia. USJP nie notuje czasowników naklektać ani klektać, ale przy formie klekotać wyróżniono znaczenie $2 \mathrm{~b}$ 'mówić dużo i głośno, często bez zastanowienia; trajkotać, klepać, paplać'. Informacje ze źródeł leksykograficznych pokazują, że czasownik w formie naklektać przestał funkcjonować w polszczyźnie ogólnej, używany jest jedynie w gwarach. We współczesnej polszczyźnie nie ma także słowa naklekotać, ale pozostała do dziś, jako czasownik mówienia, forma klekotać, nie mniej wyrazista i również dźwiękonaśladowcza, prawdopodobnie pierwotnie związana z odgłosem wydawanym przez bociana.

\section{MNIEMAĆ}

Znaczenie czasownika mniemać uwzględnione w SJPD jako jedyne stopniowo wychodzace z użycia oraz książkowe 'być zdania, uważać, sądzić, przypuszczać' zostało odnotowane także $\mathrm{w}$ SL: 'mniemam = trzymam, rozumiem, mam za to, zda mi się'. Samo znaczenie nie zmieniło się zatem w dobie nowopolskiej (co potwierdzają także znaczenia w SWil 'wyobrażać, wnosić, sądzić, zdawać się, domyślać się’ oraz SW 'myśleć, sądzić, rozumieć, utrzymywać, wyobrażać sobie, być pewnego zdania, być przekonanym'), sądząc jednak po kwalifikatorach, zmniejszył się zakres jego użycia. Co ciekawe, czasownik ten został także uwzględniony w USJP z tym samym kwalifikatorem książk., ale już bez kwalifikatora chronologicznego. Wynika $\mathrm{z}$ tego, że w połowie XX wieku ze względu na ograniczony zakres użycia wydawało się, że ten czasownik przestanie funkcjonować w polszczyźnie, okazało się jednak, że nic podobnego się nie stało. Czasownik mniemać używany jest dziś w podobnym znaczeniu: 'uważać, sądzić, przypuszczać coś, czasem nie mając pewności lub nie mając podstaw ku temu; być zdania, że...' (USJP).

\section{APLAUDOWAĆ}

SL nie notuje czasownika aplaudować. W SWil wyróżnione zostały dwa znaczenia: 1) 'klaskać rękami, dawać oklaski, dawać brawo', 2) = 'pochwalać, okryć oklaskami, w dowód zadowolenia'. Znaczenie w SJPD 'przyklaskiwać, pochwa- 
lać, wyrażać uznanie' jest zatem takie samo. Jest to kolejny przykład potwierdzający wyodrębnienie się znaczenia metaforycznego, odnoszącego się także do czynności mówienia, ze znaczenia konkretnego 'bić brawo, klaskać'. W SW pod znaczeniem 'klaskać, oklaskiwać; bić oklaski, brawo' wyodrębnione jest znaczenie: X przen. 'pochwalać; przyklaskiwać, czemuś wyrażać uznanie'. W SJPD wyróżnione zostały dwa znaczenia: a) 'oklaskiwać, bić oklaski' oraz b) z kwalifikatorem żart. 'bić'. Znaczenie przenośne 'przyklaskiwać, pochwalać, wyrażać uznanie' zostało wyodrębnione pod znaczeniem a) i nie zostało poparte żadnym cytatem. Wszystkie te znaczenia uznano za dawne, ponieważ kwalifikator znajduje się na początku artykułu hasłowego. USJP już tego czasownika nie notuje.

\section{GADULIĆ, INSTYNKTOWAĆ, NAWIESZCZYĆ}

Co ciekawe, trzech wyrazów nie odnotował żaden ze słowników oprócz SJPD: gadulić, instynktować i nawieszczyć. W tej sytuacji trudno mówić o jakichkolwiek zmianach znaczeniowych, podejrzewać można, że były to czasowniki użyte okazjonalnie, może indywidualnie, znalazły się jednak w podstawie źródłowej SJPD. Czasownik gadulić 'gadać, paplać' z kwalifikatorami daw. rzad. ilustruje jeden przykład: Gadulili wiele, bo każdy chce się popisywać swoim rozumem, czy go ma, czy nie ma. RZEW. H. Listop. I, 349.

Wyraz instynktować 'dać polecenie, rozkazywać' z takimi samymi kwalifikatorami również poparty jest jednym cytatem: Zygmunt August umierając instynktowat otaczajacym jego śmiertelne łoże panom, ażeby po jego śmierci carowi korone powierzyli. RZEW. H. Zamek 271. Może więc oba czasowniki były indywidualizmami Henryka Rzewuskiego.

W wypadku czasownika nawieszczyć 'wypowiedzieć wiele przepowiedni, proroctw, wróżb' SJPD również podaje jeden przykład: Odkąd ludzie pisać umieja niemało już nawieszczono. Tyg. Powsz. 11, 1949., słowo zostało określone w połowie XX wieku jako podnioste albo żartobliwe. Fakt, że słowniki (poza SJPD) nie odnotowały tych czasowników oraz brak większej liczby przykładów, potwierdzają ograniczony zasięg występowania tych wyrazów w dobie nowopolskiej.

\section{Zmiany znaczeniowe}

\section{Leksyka różnych odmian terytorialnych polszczyzny}

W odniesieniu do czterech jednostek leksykalnych w SJPD pojawiła się oprócz chronologicznej - informacja o obecności tych jednostek w odmianach terytorialnych polszczyzny: cudować daw. dziś. gw.; gębować przestarz. dziś gw., mrukać daw. dziś reg. oraz nakazać przestarz. reg. Wynika z tego, że w dawniejszej polszczyźnie trzy słowa miały zasięg ogólny, który następnie ograniczył się do odmiany gwarowej lub regionalnej (stąd podkreślenie $d z i s ́$ ). W wypadku wyrazu nakazać w znaczeniu 'polecić, zawiadomić' podano jedynie kwalifikator reg., 
co może oznaczać, że również dawniej zasięg występowania tej jednostki nie dotyczył polszczyzny ogólnej.

\section{CUDOWAĆ}

Czasownik cudować w SL został odnotowany w znaczeniu: 'cudaczyć, dziwaczyć, wydziwiać', poparto je przykładem: Cudujesz z czeladzia bez końca; jeśli będziesz tak cudowat, ni utrzymasz stugi. Oss. $W_{y} r^{2}$. S.B. Linde podaje także czasownik cudować się zaimk.: 'dziwować się, cudować się czemu'. W SWil podane są nie tylko te same znaczenia, ale i te same przykłady. SW podaje cztery znaczenia: 1. 'dziwactwa wyprawiać, dziwaczyć, cudaczyć, grymasić, kaprysić'; 2. 'dokazywać, zbytkować'; 3. 'niszczyć, psuć'; 4. 'wymyślać, wyrządzać obelgę'. Spośród znaczeń w tym słowniku jako czasownik mówienia oprócz zn. 1 można potraktować także zn. 4. Przy znaczeniu pierwszym SW podaje ten sam cytat dotyczący czeladzi, który pojawił się we wcześniejszych źródłach. Jest to jedyny przykład, zwraca natomiast uwagę, że definicja została sformułowana inaczej, podano bowiem kolejne wyrazy bliskoznaczne: grymasić i hałasować. W definicji jedynego zawartego w SJPD znaczenia te wyrazy pozostały: 'grymasić, kaprysić, dziwić się, postępować dziwacznie; wydziwiać' (z przykładem: Nie opowiadaj też, żem tu była, żeby nade mna nie cudowali. SIENK. Krzyż. I, 200.), a nawet zostały wysunięte na pierwsze miejsce. Jest to jeden z niewielu omawianych czasowników zanikających $\mathrm{w}$ dobie nowopolskiej, który został uwzględniony w USJP z kwalifikatorem pot. (a zatem o ograniczonym zasięgu występowania) w znaczeniu: 'wydziwiać, grymasić, kaprysić; także: dziwić się'.

\section{GĘBOWAĆ}

W SL czasownik gębować notowany jest w dwóch znaczeniach: 'szkalować' (zapisane zresztą błędnie jako szkałować), gdzie poparty jest dwoma przykładami: Wymówcy, którzy umieja gębować na ludzie zacne i majętne, bardzo się podobaja pospólstwu. Petr. Pol. 2, 57. Zwyciężone jeszcze bardziej gębowały. Zebr. Ow. 126. ib. 308.; oraz jako termin flisacki, nieobjaśniony dokładnie, który jednak w kontekście badanego problemu nie jest istotny. W SWil oprócz (wyodrębnionego zresztą jako drugie) znaczenia flis. 'zamawiać', znajduje się znaczenie takie samo jak w SL: z kwalifikatorem prze. (wyraz przestarzały) 1) 'szkalować, szczekać’ z przykładem: Gębować na kogo. Bardziej szczegółowo i nieco inaczej definiuje ten czasownik SW 1. 'hardo odpowiadać, dowodzić, szczekać, pyskować, ujadać'; 2. 'rozprawiać głośno, dowodzić wiele', 3. $f$. 'statek na gębę chwytać, przymocowywać'. Dokonała się tu wyraźna zmiana znaczenia.

Aby sprawdzić, co mieli na myśli autorzy SW, warto odwołać się do definicji czasownika szkalować. Ma on dwa znaczenia: 1. 'łajać, lżyć, besztać, wymyślać; szczypać słowami, pikować, natrząsać ś., kpić, szydzić, dogryzać' oraz 2. 'czer-

${ }^{2}$ Cytaty oraz definicje z pierwszego wydania SL zostały przetranskrybowane, aby nie odwracać uwagi od treści. 
nić, oczerniać kogo, psy na kim wieszać, obmawiać, szarpać językiem'. Szkalowanie i gębowanie w SW jest zatem rozumiane dwojako: wymyślanie, krzyczenie na kogoś lub oczernianie, czyli mówienie o kimś źle niezgodnie z prawdą. Znaczenie określone w SJPD jako przestarz. dziś gw. 'arogancko odpowiadać; wymyślać komuś, pyskować; rozprawiać głośno, gardłować' to jedyne znaczenie tego czasownika, potwierdzone dużą liczbą przykładów, np. Tylko gębować umiecie jak przekupki, jak krupne baby zza straganów, nie jak na szlachtę, nie jak przystoi na panów! Zabt. Sarm. 26. Oznacza to, że dwa znaczenia obecne we wcześniejszej polszczyźnie wyszły z użycia (związane z oczernianiem oraz flisackie). Ze znaczenia 'szkalować', które ostatni raz odnotował SWil wykształciły się dwa znaczenia: 'hardo odpowiadać, pyskować' oraz 'hałasować'. Wydaje się, że jest to przeniesienie nazwy poprzez przesunięcie centrum dominanty znaczeniowej. Można wszak kogoś szkalować bez krzyczenia, hałasowania, czy nawet podnoszenia głosu. USJP również notuje formę gębować z kwalifikatorem chronologicznym przestarz. 'wymyślać komuś, pyskować, rozprawiać głośno; gardłować': Gębowała jak przekupka. Wprawdzie z odcieniem archaiczności, ale jednak wyraz ten funkcjonuje nadal w ogólnej polszczyźnie współczesnej, w USJP nie ma bowiem kwalifikatora informującego o używaniu go jedynie w odmianach terytorialnych.

MRUKAĆ Czasownik mrukać nie został odnotowany w SL oraz SWil. W SW znalazło się odesłanie: p. mruknać: 1. 'zamruczeć, zamamrotać, burknąć, oburknąc się, bąknąć pod nosem'; 2. a) 'zabeczeć, beknąć (o kozie)', b) 'ryknąć, zaryczeć cicho (o krowie)'; c) 'zawarczeć, zawarknąć'. Jedynie pierwsze z tych znaczeń odnosi się do czynności mówienia. W SJPD znalazło się odesłanie do jednego ze znaczeń czasownika mruczeć: p. mruczeć (w przykładzie w zn. 2): 'mówić, śpiewać niewyraźnie, cicho; mamrotać; wydawać nieartykułowane, niskie dźwięki naśladujące głos niektórych zwierząt, np. kota'. To kolejny czasownik - po naklektać - o znaczeniu metaforycznym, pierwotnie określający odgłosy zwierząt. Samo mrukać zostało jednak udokumentowane cytatem: I my słali się pokotem. A jeszcze do siebie powiastkami o swych bojach mrukali w omroczu. ZAL. BOH. Zbar. 68. USJP nie notuje czasownika mrukać, a jedynie hasło mruknać - mruczé́, gdzie odnotowane zostały wszystkie wymienione powyżej, a także jeszcze inne znaczenia (np. 4. 'narzekać, szemrać, protestować (niezbyt głośno)'). Forma mrukać zanikła w polszczyźnie ogólnej, wyparta przez mruczeć.

\section{NAKAZAĆ}

W SJPD jako jedno z trzech znaczeń czasownika nakazać zostało wyodrębnione znaczenie szczegółowe 'polecić, zawiadomić' oznaczone jako przestarzałe i regionalne, które znalazło się w słowniku obok znaczeń: 1. 'wydać nakaz; zarządzić, polecić' oraz 2. 'stanowić konieczną rację jakiegoś postępowania'. Znaczenie zanikające zostało poparte tylko jednym przykładem: Uważaj mnie zawsze za 
twego dlużnika i jeślibyś kiedy potrzebowat czego z Paryża, nakaż do mnie, a ja wedle możności zastapię twoję kasę. MICK. Listy II, 172. Wyodrębnione tu znaczenie jest bliskie znaczeniu pierwszemu, ponieważ objaśnienie obejmuje również wyraz bliskoznaczny polecić.

Objaśnienia podane w SL to 'nauczać, napominać' (bez przykładu, a jedynie z odpowiednikami obcojęzycznymi) oraz 'przykazać, zapowiadać, stanowić'. Z przykładów wynika przede wszystkim znaczenie nakazu: Trudu tego, choćby ci nikt go nie nakazowat, jednakże... Pilch. Sen. list. 2, 295. oraz Czułość w sercu wzbudzona, ale nie nakazana być może. Węg. Mar. 1, 63. W SWil odnotowane zostało jedno znaczenie 'zalecać, rozporządzać, zapowiadać, przykazywać' z przykładami: Nakazywać pańszczyznę. Nakazano zjazd. Nakazać komu milczenie. Wypetniać to, co prawo nakazuje. SW notuje dwa znaczenia: 1. 'zalecić, rozporządzić, zapowiedzieć, przykazać, postanowić'; 2. prow. 'ustnie coś przez kogoś polecić', znalazło się w tym słowniku zatem także (jako drugie) znaczenie wyodrębnione w SJPD. W SW znajduje się przy nim tylko jeden cytat: Litery nie napisać, nie nakazać słówka. Mick. W związku z tym, że znaczenie to zostało odnotowane jedynie w SW oraz SJPD, a potwierdzone w obu źródłach tylko po jednym użyciu, w dodatku w obu z tekstów Adama Mickiewicza, nie można tu chyba mówić o zmianie znaczeniowej w ogólnej polszczyźnie, a raczej o indywidualnym użyciu tego czasownika. Współcześnie słowo nakazać funkcjonuje jako książkowe: USJP a) 'wydać (wydawać) nakaz, zarządzenie, polecić (polecać) coś zrobić'; b) 'stanowić konieczną rację, model jakiegoś postępowania'.

\section{Różne rejestry polszczyzny (frekwencja, styl)}

Wśród kwalifikatorów uzupełniających informację dotyczącą chronologizacji poszczególnych jednostek hasłowych oraz jednostek leksykalnych (wyodrębnionych znaczeń) znaczna część odnosi się do częstotliwości użycia (rzad. - pięć jednostek), wyodrębnionych znaczeń metaforycznych (przen. - cztery jednostki oraz jedna w obu wymienionych grupach (przen. rzad.)) lub do przynależności jednostki do określonych rejestrów stylistycznych (np. żart., zwykle żart., książk., dziś książk., pot., dziś podn. a. żart.).

Jako wyrazy nacechowane chronologicznie dawnością, a występujące rzadko w polszczyźnie XX wieku, redaktorzy SJPD uznali m.in. takie formy, jak: dekurażować, gadulić, instynktować, markotać 2, molestować 2, a flecić 2 uznano za rzad. przen. Niektóre z nich zostały omówione powyżej, poniżej znajduje się charakterystyka pozostałych.

\section{DEKURAŻOWAĆ}

W SL brak hasła dekurażować. W SWil uwzględniono je ze znaczeniem 'odbierać komu odwagę, czynić kogo nieśmiałym', nie podano jednak żadnego przykładu, a sama definicja nie wskazuje, czy jest to czasownik mówienia, czy też 
komunikaty werbalne nie są konieczne. Według SW dekurażować kogo z kwalifikatorem X (mało używany) oznacza 'odbierać mu kuraż, onieśmielać, przestraszać go', również brakuje tu jednak przykładów. W USJP hasła brak. Więcej wiadomości zawiera zatem tylko SJPD, który podaje jedno przestarz. i rzad. znaczenie 'odbierać komuś odwagę, energię; zniechęcać, zrażać kogoś' i ilustruje je jednym przykładem: Mówię ci to, nie żeby cię dekurażować, ale żebyście wiedzieli, z jakimi siłami zaczynacie działać. Twórcz. 3, 1951, s. 79. Dane leksykograficzne są zatem w tym wypadku zdecydowanie niewystarczające, aby stwierdzić, jak słowo to funkcjonowało w komunikacji językowej, choć przytoczony przykład potwierdza, że chodzi o czynność mówienia.

\section{MARKOTAĆ 2}

W wypadku czasownika markotać SL notuje jako pierwsze znaczenie związane z czynnością mówienia: 'mrucząc odwarkać, szemrać, mamrotać, mamrzeć'. Z przykładu: Markotaliście przeciwko mnie. 1. Leop. Num. 14. wyprowadzone zostało znaczenie 'szemrać'. Oprócz tego znajduje się jeszcze znaczenie odnoszące się do zwierzęcia 'o niedźwiedziu: mruczeć, mamrzeć'. SWil podaje znaczenie 'mruczeć pod nosem, szemrać, niewyraźnie mówić' jako ob. szemrać, w słowniku nie ma żadnej ilustracji tekstowej. W SW znajduje się odesłanie do hasła mamrotać, tam z kolei podanych znaczeń jest więcej: p. mamrotać: 1. a) 'mówić niewyraźnie, mruczeć pod nosem, cicho, niezrozumiale, niewyraźnie coś mówić, bąkać'; b) 'mruczeć gniewliwie, szemrać, gderać, zrzędzić, burczeć'; c) 'wiele mówić'; 2. 'mówić bez sensu'. W SJPD również znajduje się odesłanie do jednego ze znaczeń czasownika mamrotać (zn. 2) 'gderać, zrzędzić; burczeć gniewnie', jeden przykład stanowi ilustrację: Musiały zatem wstawać, markoczac pod nosem: „, Czy cię piekielnik rozpierzyt, psi ptaku, i z twoim przemierzlym głosem!" TREMB. Bajki 11. W USJP hasła brak. W połowie XX wieku czasownik markotać został określony jako dawny i rzadki, poświadczony zaś tylko w jednym znaczeniu. Następnie wyszedł z użycia w polszczyźnie ogólnej; rejestrowany jest w Słowniku polskich leksemów potocznych, pod red. W. Lubasia.

\section{MOLESTOWAĆ 2}

W SL czasownik molestować kogo został wyodrębniony pod hasłem molestia (notowane jako molestya) 'przykrość', jako cz. ndk, obok dk umolestować w znaczeniu 'przykrzyć mu się, naprzykrzać mu się, uciążać go’ z przykładami: Żeby go żaden o żadna rzecz nie gabat, ani molestowat. 1 Leop. 1 Mach. 10, 63. Dzieci nie ćwicza, aby ich nie strudzili i molestowali. Petr. Pol. 2, 333. W SWil podano znaczenie 'naprzykrzać się komu; być natrętnym, usilnie prosić' bez przykładów. W SW wyróżniono trzy znaczenia różnie kwalifikowane: 1. X 'męczyć, fatygować, trudzić, nękać, obciążać, dręczyć, dokuczać, dawać ś. we znaki, przykrość wyrządzać'; 2. 'naprzykrzać się komu prośbami, prosić do znudzenia, usilnie, błagać rzewnie'; 3. [M.] 'narzekać, ubolewać'. Tylko drugie znaczenie ilustrowane jest przykładami: jeden to zdanie z Biblii Leopolity za SL, pozostałe to: Mole- 
stowana panna siadła do fortepianu i grać zaczęła. Orzesz. Każdy widzi, że nas molestują o rzecz próżna, nic do nas nie należaca. Kit. W SJPD podane są również trzy znaczenia: 1. 'natrętnie o coś prosić, nudzić prośbami; naprzykrzać się o co' bez żadnych kwalifikatorów, oraz z kwalifikatorami przestarz. rzad. 2a. 'dawać się we znaki; nękać, dokuczać' oraz $2 \mathrm{~b}$ nieprzechodnio 'biadać, narzekać, ubolewać'. Znaczenia te kontynuują zatem te notowane w SW. W USJP sytuacja przedstawia się zupełnie inaczej: książk. a) 'natrętnie o coś prosić, nudzić ciągłymi prośbami; naprzykrzać się'; b) 'nakłaniać kogoś do kontaktów seksualnych wykorzystując swoją przewagę, zwykle w stosunkach służbowych lub wobec dzieci'. Pierwsze znaczenie, które w SJPD nie było oznaczone kwalifikatorem, nadal jest więc obecne w polszczyźnie, jednak z ograniczeniem do stylu książkowego. Znaczenie związane z kontaktami seksualnymi można potraktować jako zawężenie znaczenia podstawowego, jednak prawdopodobnie jest to zapożyczenie semantyczne z języka angielskiego.

\section{FLECIĆ 2}

Czasownik flecić nie został odnotowany w SL oraz SWil. W SW znalazł się wraz ze znaczeniem 'grać na flecie' z przykładem: Niech fleci pacholę. Uj. W SJPD jest to znaczenie podstawowe opatrzone kwalifikatorami przestarz. rzad. Pod nim zostało jednak wyodrębnione jeszcze znaczenie metaforyczne: 'grać, pisać, wypowiadać się rzewnie, sentymentalnie, smętnie' wraz przykładem: Sypaty się romanse, triolety, gazele, piosenki i pieśni - gdy na koniec Izabela zawołała: - Same erotyczności, same skargi i treny milosne flecisz nam tylko, panie Konradzie. Wilk. P. Poran. II, 72. W USJP hasła brak. Jest to zatem przykład powstania znaczenia metaforycznego związanego ze sposobem wypowiadania się, a wywodzącego się ze znaczenia konkretnego związanego z muzyką.

Kolejne przykłady obejmują jednostki leksykalne, które oprócz kwalifikatorów chronologicznych uzyskały w SJPD oznaczenie przen., są to zatem znaczenia metaforyczne.

\section{KOLOROWAĆ}

W SL czasownik kolorować objaśniony jest wraz z formą koloryzować (cz. $n d k$ ) oraz ukolorować ( $d k)$ w znaczeniu 'farbować, kolorem napuszczać, barwić'. Do wszystkich trzech czasowników przykłady są tylko dwa: Ukoloruję sobie brwi. Teat. 16 b, 100. Części kolorujące lnu. N. Pam. 6, 317. Przy czasowniku kolorować w SWil wyodrębniono dwa znaczenia: 1. 'farbować, kolorem napuszczać, barwić' oraz 2., przy którym znajduje się odesłanie do hasła koloryzować. Przy tym czasowniku z kolei również wyodrębniono dwa znaczenia 1. konkretne w odniesieniu do sztychu, rysunku: 'naprowadzać kolorami' oraz 2. metaforyczne (zresztą opatrzone kwalifikatorami) fig. posp. 'wymawiać, usprawiedliwiać'. Koloryzować niesprawiedliwość, kłamstwo. SW oprócz znaczenia 'malować, naprowadzać kolorami, barwić', podaje także formę kolorować się określoną jako gwarowa w znaczeniu 'błyszczeć'. W SJPD znaczenie podstawowe to - podobnie 
jak we wcześniejszych słownikach - 'nadawać kolor; barwić, malować, farbować', pod nim zostało jednak wyodrębnione znacznie przen. przestarz. 'upiększać, urozmaicać (por. koloryzować) z ilustracją w postaci cytatów: O Francji, o rewolucji, o rzymskich wypadkach mówiliśmy - on naturalnym, ale kolorowanym stowem i niespodziewanymi obrotami mowy. NORWID Wspom. 77. Malowat on [Pasek] przeszłość, kolorując zapewne gote tylko szkice notatek swoich. MARC. Pisma II, 8. W USJP czasownik kolorować ma inne znaczenia: 1. 'nadawać czemuś jakiś kolor; malować, farbować, barwić' oraz specjalistyczne 2. muz. 'w muzyce XVI-XVII w.: ozdabiać kompozycje muzyczne, zwłaszcza instrumentalne, przez wprowadzanie różnego rodzaju form ozdobnikowych, ornamentów, odmian wariacyjnych itp.' . W omawianym tu znaczeniu występuje jednak w USJP czasownik koloryzować 1. 'przesadzać w opowiadaniu, opisie, ubarwiać, upiększać relacje zmyślonymi szczegółami’.

\section{MALOWAĆ}

SL odnotowuje kilka znaczeń czasownika malować: 'farbami figury wyrażać'; 'malować, pomalować stół, laskę, farbować' oraz fig. 'zdobić, przyozdabiać, pstrzyć, barwić'. Najbliższe czynności mówienia, ponieważ związane z wyrażaniem uczuć, jest znaczenie wyprowadzone z przykładu: recipr. Smutek się maluje na twarzy. Teatr 38, 212, 'przebija się, odbija się, wyraża się'. SWil podaje te same znaczenia, co SL, natomiast znaczenie związane z czynnością mówienia wyodrębnione zostało jako 4) = fig. 'przedstawiać, opisywać, opowiadać'. Kiedy nie znasz tego człowieka, postuchaj jak go maluja. Malowano nam charakter jego w najczarniejszych kolorach.

Autorzy SW podali jeszcze więcej znaczeń oprócz tych, które pojawiły się w źródłach wcześniejszych (5. X przen. 'pisać, okazywać na piśmie', 6 [malować] a) 'obmawiać, oczerniać', b) 'iść pomału, wlec ś.', c) 'kręcić, wykręcać ś., wyłgiwać ś.'). W SJPD znaczeń jest już mniej, oprócz znaczenia 1. 'powlekać, pokrywać co farbą, lakierem itp;; nadawać czemu kolor; barwić, znajduje się jeszcze 2. 'tworzyć obraz, dzieło malarskie, pokrywać co malowidłami, wzorami'. Pod tym znaczeniem wyodrębniono dwa metaforyczne odcienie znaczeniowe, jeden z kwalifikatorem przen. a) 'opowiadać o czym, opisywać co; przedstawiać, wyobrażać’ z licznymi poświadczeniami (np. Wielu z przybywajacych spiskowców rosyjskich i polskich malowało wzruszajace obrazy z dalekiej ojczyzny. WOJTK. Gen. 280.) oraz b) przen. przestarz. 'wyrażać, uzewnętrzniać'. Drugie znaczenie jest również poparte przykładami, z których najbardziej wyrazisty to: Wzią mię za rękę i mówit głosem, malującym głębokie rozrzewnienie: Jak mi żal, jak mi żal, że tak krótko jesteśmy z sobq. GOSZ. Król 198. W USJP znalazło się również jedno ze znaczeń odnoszących się do czynności mówienia: 4. książk. 'opowiadać o czymś lub o kimś, opisywać, przedstawiać coś lub kogoś żywo, zajmująco, plastycznie, barwnie'. 


\section{MAZAĆ}

Znaczenie czasownika mazać określone w SJPD jako nacechowane chronologicznie dawnością zostało wyodrębnione pod zn. 1. 'powlekać, pociągać coś, smarować, namaszczać, brudzić, walać jakąś substancją mazistą', tu dodatkowo wynotowano: przen. przestarz. 'kalać, plugawić, szkalować, bezcześcić'. W zasadzie to znaczenie jest już obecne w SL, jednak widać wyraźnie, w jaki sposób wyodrębniło się ono ze znaczenia konkretnego 'kalać, plugawić', z przykładem m.in. Zly to ptak, co swe gniazdo maże. Hipp. 55. Metaforycznie czasownik ten został użyty w przykładzie: Jeżeli mąż wolny z cudza żona sprawę miał, tedy cudze toże nierządem cudzołożnym maże się. Kucz. Kat. 3, 146. oraz w przykładzie: Nic jadowitszego nie masz, co by nad nieuczciwe ludzkie bardziej lżyto, $i$ sromociło i mazało. Veryf. pr. 2. z wyjaśnieniem podanym po przykładzie 'hańbiło'. Kolejny przykład wskazuje już na czynność mówienia: I nam by też przystało nie mazać nikogo, Gdyż o ludzie bez winy dziś na świecie drogo. Papr., Kot. E. objaśnione jako: 'lżyć, *bezeczcić'. W SWil większość znaczeń powtórzono za SL, nie zostało jednak odnotowane znaczenie związane z czynnością mówienia, a jedynie 3. fig. 'hańbić, kalać, plamić' z przykładem: Mazać swój honor występkiem, zdrada. W SW jako zn. 4. odnotowano przen. 'hańbić, bezcześcić, znieważać, zniesławiać, profanować, kalać, plamić; czernić'. USJP przy haśle maznąc - mazać podane są cztery znaczenia: 1. 'ubrudzić (brudzić) coś lub kogoś czymś, co się rozmazuje; poplamić (plamić), usmarować (smarować)'; 2. 'pokryć (pokrywać), posmarować (smarować) coś czymś mazistym'; 3. 'zetrzeć (ścierać) to, co zostało napisane lub narysowane; wytrzeć (wycierać), skreślić (skreślać, kreślić)'; 4. pot. «napisać (pisać) lub narysować (rysować) coś, zwykle szybko, niestarannie; nabazgrać (bazgrać), nagryzmolić (gryzmolić). Żadne z nich nie odnosi się już ani do czynności mówienia 'bezcześcić, zniesławiać', ani nawet do innych kwestii związanych z oceną moralną.

$\mathrm{W}$ tej grupie czasowników, tj. opatrzonych kwalifikatorem przen. przestarz., zwraca uwagę obecność czasowników w prymarnym znaczeniu związanych z kolorowaniem, malowaniem, mazaniem. Określają one wówczas taką czynność mówienia, która wiąże się z ubarwianiem w słowach rzeczywistości.

W SJPD zostały ponadto odnotowane wyrazy z kwalifikatorem ksiażkowe. Są to trzy czasowniki: konwersować, fajnować i mościć.

\section{KONWERSOWAĆ}

W SL rzeczownik konwersacja oraz czasownik konwersować z kim wyodrębnione są bez wysunięcia pierwszego wiersza z gwiazdkami pod hasłem konwers, konwirs. Przy czasowniku znajduje się znaczenie 'przestawać, obcować z kim' wraz z informacją med. niedok. Przykłady to: Wstawszy z martwych Pan konwersowat z swemi wybranemi apostoły. Kochow. Roż. 53. Wiele mówiacych wystrzegat się, i z niemi mało konwersowat. Skarg. Żyw. 2, 46, nie potwierdzają one, że jest to czasownik specjalistyczny związany z medycyną. SWil nie podaje czasownika konwersować, a jedynie rzeczownik konwersacja 'rozmowa' z przykładami: 
Konwersację z kim prowadzić. Ożywiać konwersację. Informacja w SW obejmuje oba znaczenia przywołane w SL: 1. 'rozmawiać' oraz 2. X z kim = 'obcować, przestawać' z jednym przykładem (za SL): Wiele mówiacych wystrzegat ś. i z niemi mało konwersowat. Skar.

W SJPD oraz w USJP czasownik konwersować został zamieszczony w tym samym znaczeniu i z takim samym kwalifikatorem książk. (w SJPD dziś książk.) 'prowadzić rozmowę towarzyską, rozmawiać z kimś'. Znaczenie związane z przebywaniem, obcowaniem z kimś odeszło już do przeszłości, pozostało natomiast to związane z prowadzeniem rozmowy. Wydaje się, że niektóre przykłady zamieszczone w SJPD nie do końca odpowiadają na pytanie, czy na pewno chodzi o znaczenie związane z rozmową: Muszę nauczyć pana Starościca konwersować $z$ damami! AUD. Zbieg. 61; może tu mieć znaczenie nie 'rozmawiać', lecz 'obcować', czyli równie dobrze cytat może się odnosić do przebywania w towarzystwie dam. Ta zmiana znaczenia wydaje się bardzo naturalna. Obcowanie z kimś polega przede wszystkim na rozmowie, więc doszło tu do przeniesienia przez metonimię, czyli styczność.

\section{FAJNOWAĆ 2}

Jako żartobliwe zostało określone znaczenie czasownika fajnować odnotowane w SJPD. SL notuje ten czasownik jako feynować, feinować (cz. ndk), cienkim czynić' z przykładami: Feynowanie monety. Pam. 85, 1, 63. Dowcipnie feinowane bałamuctwa. Pilch. Sen. list. 4, 120, po którym znajduje się jeszcze wyjaśnienie: 'subtylizowane'. SWil nie notuje żadnego z wariantów czasownika. W SW znalazły się dwa znaczenia 1. X fejnować hut. 'oczyszczać kruszce, np. srebro od ołowiu (za pomocą topienia), rafinować, fryszować' oraz 2. żart. 'kłamać'. SJPD odnotował te same znaczenia co SW, oba jako przestarzałe, a 'kłamać, oszukiwać' dodatkowo jako żartobliwe. Niestety nie zostały one poparte żadnymi przykładami. W USJP tego hasła brak.

\section{MOŚCIĆ II}

Przestarzałe i zwykle żartobliwe jest według SJPD znaczenie czasownika mościć II ‘tytułować miłościwym panem, mości panem, mościem'. W SL oraz SWil notowane jest jedynie słowo mościć $I$, formy homonimicznej słowniki nie zawierają. W SW znajduje się czasownik mościć II z odesłaniem do mościać (a tam jeszcze forma mościwać kogo ‘tytułować go mościwym panem') w znaczeniu 'nawzajem ś. tytułować mościwemi panami' z przykładami: U nas niema (sic!) zwyczaju tak ś. M. mościami. Sienk. Nie mośćmy ś. mościami, skoro nas nikt nie słyszy. Sienk. W SJPD pod przywołanym znaczeniem nie ma żadnego przykładu, jest jednak pod wyodrębnionym mościć się 'tytułować się tak wzajemnie': Tylko mi pan daj spokój z pryncypatowaniem! U nas nie ma zwyczaju tak się mościć mościami albo pryncypałować. SIENK. Polan. II, 199. W USJP hasła mościć II, ani też mościać ze zrozumiałych względów już nie ma. 


\section{Wnioski}

Wybrane na podstawie SJPD czasowniki mówienia stanowiły dość dużą grupę czasowników wychodzących z użycia w dobie nowopolskiej: na 1595 czasownikowych jednostek leksykalnych rozpoczynających się na litery od A do N jest ich 234, czyli stanowią około $15 \%$ wszystkich wybranych jednostek. Przy 209 jednostkach z tej grupy w SJPD zamieszczono jedynie kwalifikator chronologiczny: dawny, przestarzały, wychodzacy z użycia. Tylko w odniesieniu do 25 jednostek leksykalnych w tym słowniku znalazły się ponadto inne kwalifikatory. Dotyczyły one częstotliwości występowania (rzad.), znaczeń metaforycznych (przen.), różnych rejestrów stylistycznych (książk, żart.) czy wreszcie przynależności do terytorialnych odmian polszczyzny ( $g w$., reg., $d z i s ́$ gw.). To właśnie słownictwo jako szczególnie interesujące ze względu na zmieniający się zakres użycia zostało poddane analizie leksykograficznej pod względem zachodzących w nim zmian.

W artykule przedstawione zostały zmiany w znaczeniu wybranych czasowników mówienia zanikających w dobie nowopolskiej. Interesujące jest to, że znaczenie części jednostek leksykalnych nie zmieniło się w ciągu doby nowopolskiej (łącznie 8 jednostek leksykalnych, np. aplaudować, hałasić), a także fakt, że niektóre jednostki nie zostały uwzględnione w żadnym ze źródeł leksykograficznych oprócz SJPD, który to słownik stanowił podstawę badawczą analizowanego materiału (gadulić, instynktować, nawieszczyć).

Omawiany wycinek rzeczywistości językowej jest zbyt wąski, by próbować wskazać tendencje czy prawidłowości dotyczące zarysowujących się zmian znaczeniowych. Przeprowadzone zostaną dalsze badania nad materiałem. Przekształcenia przestawione powyżej, a dotyczące konkretnych czasowników, reprezentowały zjawiska bardzo różnorodne, podobnie tempo zmian również nie było takie samo, więc trudno w tej chwili formułować wiążące wnioski końcowe. Zjawiska zachodzące w relacjach między znaczeniami oraz między różnymi bliskoznacznymi czasownikami są na tyle wielokierunkowe, że muszą zostać przeanalizowane bardziej szczegółowo. Dalsze badania nad pozostałymi czasownikami mówienia wychodzącymi z użycia $\mathrm{w}$ dobie nowopolskiej pozwolą zaobserwować wspólne cechy, prawidłowości w zakresie odchodzenia w niepamięć poszczególnych jednostek leksykalnych. Już tu jednak warto wskazać ciekawe zjawisko użyć metaforycznych takich czasowników, które pierwotnie odnoszą się już to do odgłosów zwierząt (naklektać, mrukać), już to do sztuki - głównie plastycznej (malować, kolorować), ale też muzyki (flecić), w przenośnym znaczeniu używane jako verba dicendi. Ich wychodzenie z użycia warunkowane jest różnymi przyczynami, m.in. zmianą formantu, np. mrukać wobec mruczeć. Obecność innych w SJPD, a nieobecność w słownikach najnowszych wynika też z założeń podejmowanych prac leksykograficznych. Przykładowo czasownik malować, choć w znaczeniu związanym z czynnością mówienia został opatrzony kwalifikatorem przen. przestarz., wciąż może być używany, por. USJP: 4. ksiażk. 'opowiadać o czymś lub o kimś, opisywać, przedstawiać coś lub kogoś żywo, zajmująco, plastycznie, barwnie’. 


\section{ROZWIĄZANIE SKRóTóW}

SJPD - Słownik języka polskiego, red. W. Doroszewski, t. 1-11, Warszawa 1958-1969 (reprint).

SL - S.B. Linde, Słownik języka polskiego, Warszawa 1807-1814 oraz wyszukiwarka Poliqarp, http://korpusy.klf.uw.edu.pl/pl/slownik-lindego.

SW - J. Karłowicz, A.A. Kryński, W. Niedźwiedzki, Słownik języka polskiego, Warszawa 1900-1927 (słownik warszawski) oraz wyszukiwarka Poliqarp, http:// korpusy.klf.uw.edu.pl/pl/slownik-warszawski/.

SWil - Słownikjęzyka polskiego, wyd. staraniem M. Orgelbranda, Wilno 1861 (słownik wileński); także: Słownik wileński: http://eswil.ijp-pan.krakow.pl/index.php.

USJP - Uniwersalny słownik języka polskiego, red. S. Dubisz, t. 1-4, Warszawa 2003.

\section{Bibliografia}

Chojak J., 2006, Semantyka i składnia czasowników oznaczajacych reakcje słowne, Warszawa.

Duraj-Nowosielska I., 2007, Czasowniki nazywajace czynności mowy i ich nieagentywne odpowiedniki. Wstęp do analizy semantycznej z perspektywy opozycji agentywności i kauzatywności, „Prace Filologiczne”, t. 52, s. 59-88.

Kierkowicz M., 2011, ,, Verba dicendi” w ,, Sprawie chędogiej” i „Rozmyślaniu przemyskim”, „Kwartalnik Językoznawczy”, 1 (5), s. 13-22.

Kleszczowa K., 1989, , Verba dicendi” w historii języka polskiego. Zmiany znaczeń, Katowice.

Kleszczowa K., 1991, Historyczna motywacja refleksywnych postaci czasowników, „Prace Językoznawcze. Studia Polonistyczne”, 19, s. 91-99, http://www.sbc.org.pl/Content/82432/13.pdf [dostęp: 14.04.2015].

Kozarzewska E., 1990, Czasowniki mówienia we współczesnym języku polskim: studium semantyczno-składniowe, Warszawa.

Stępień M., 2009, Mówienie i prawda. O czasownikowych wykładnikach wiedzy niezweryfikowanej przez mówiącego, Warszawa. 